
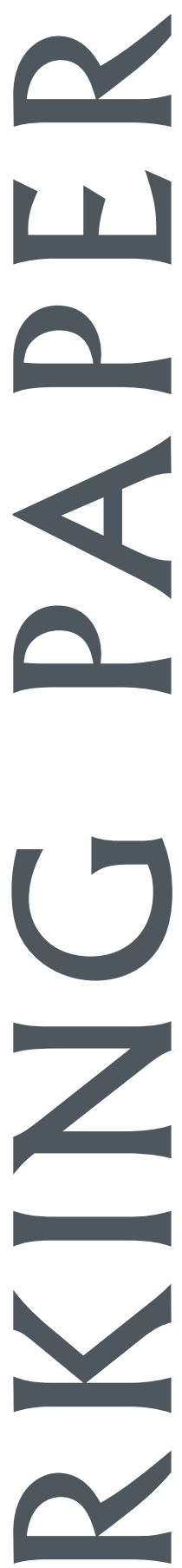

EAST-WEST CENTER 
The U.S. Congress established the East-West Center in 1960 to foster mutual understanding and cooperation among the governments and peoples of the Asia Pacific region including the United States. Funding for the Center comes from the U.S. government with additional support provided by private agencies, individuals, corporations, and Asian and Pacific governments.

East-West Center Working Papers are circulated for comment and to inform interested colleagues about work in progress at the Center.

For more information about the Center or to order publications, contact:

Publication Sales Office

East-West Center

1601 East-West Road

Honolulu, Hawaii 96848-1601

Telephone: 808-944-7145

Facsimile: 808-944-7376

Email: ewcbooks@EastWestCenter.org

Website: www.EastWestCenter.org 


\title{
National Sovereign Economy, Global Market Economy, and Transnational Corporate Economy
}

\author{
Dieter Ernst and Terutomo Ozawa
}

Dieter Ernst is a Senior Fellow and Theme Leader for economic studies at the East-West Center. He is also a research professor at the Center for Technology and Innovation (TIK) at the University of Oslo. His previous affiliations include the OECD, Paris, as senior advisor; the Berkeley Roundtable on the International Economy; the University of California at Berkeley as senior fellow; and the Copenhagen Business School as professor of international management. He is coeditor of International Production Networks in Asia: Rivalry or Riches? (2000) and Technological Capabilities and Export Success in Asia (1998). He serves on the Committee on Information Technology and International Cooperation (ITIC) of the U.S. Social Science Research Council. He also serves as scientific advisor to the United Nations University's Institute for New Technologies (UNU-INTECH), Maastricht, Netherlands; and the Japan Foundation's Globalization Project.

Terutomo Ozawa was a Visiting Fellow at the East-West Center, and is currently a professor of economics at Colorado State University, and a Research Associate at the Center on Japanese Economy and Business at the Columbia Business School. Previous affiliations include visiting professor at the University of Tokyo (Institute of Social Science), short-term visiting professor at the University of Paris I (PantheonSorbonne), visiting research associate at MIT, and consultant for OECD, World Bank, UNCTAD, and other international organizations. His latest book is Business Restructuring in Asia: Cross-border Mergers and Acquisitions in the Crisis Period co-authored by James Zhan of UNCTAD, Copenhagen Business School Press, 2001.

This paper has been accepted for publication in the Journal of Economic Issues, June 2002. 
(continued)

East-West Center Working Papers: Economics Series reports on research in progress. This paper has been peer-reviewed. The views expressed are those of the authors and not necessarily those of the Center. Please direct orders and requests to the East-West Center's Publication Sales Office. The price for Working Papers is $\$ 3.00$ each plus postage. For surface mail, add $\$ 3.00$ for the first title plus $\$ 0.75$ for each additional title or copy sent in the same shipment. For airmail within the U.S. and its territories, add $\$ 4.00$ for the first title plus $\$ 0.75$ for each additional title or copy in the same shipment. For airmail elsewhere, add $\$ 7.00$ for the first title plus $\$ 4.00$ for each additional title or copy in the same shipment. 
In neoclassical international economics the national sovereign economy is the standard unit of analysis, and there exists only a market-driven cross-border economy (which is hereafter called the global market economy) whose efficiency is hindered only by transportation costs and other transactional barriers to cross-border activities.

With the emergence of multinational corporations, which transcend the individual national economies, however, there has emerged a "third" economy or a global economic system that coexists with both the national sovereign economy and the global market economy. This study conceptualizes what is called "transnational corporate economy" as an additional sub-structure of the world economic system. This conceptualization is useful in understanding the much-talked-about phenomenon of globalization by way of differentiating the present trend of globalization from its earlier (pre-World-War-I) counterpart and examining the nature and welfare implications of the integrated global economy.

\section{Triumvirate World Economy}

As to the structure of the cross-border economy, two contrasting perspectives have emerged, as illustrated in Figured 1. Neoclassical economics conceives the world economy as a market-coordinated (guided by the "invisible hand") entity. It is fragmented into a multiplicity of economic systems because "each economic system is necessarily bounded" (Pasinetti 1993) in order to execute effective macro-stabilization measures (fiscal and monetary) and macro-organizational policies (welfare and labor practices). These sovereign economies are linked by the "invisible hand" when they engage in international commerce. 
This perspective prevails in all trade theories ranging from Ricardo's theory of comparative advantage and the Heckscher-Ohlin factor endowment theory to more recent "new" theories that emphasize increasing returns, product differentiation, and historical accident-cum-path dependence. Market failures are recognized, but they are of the "structural" type — that is, monopolistic elements and externalities which can be dealt with by appropriate governmental measures (e.g., regulations and fiscal measures). The primacy of market is the order of the day. The existence of multinational corporations, which are best described as the "creatures of market imperfections" (Hymer 1960/1977), has only lately been recognized but still remains largely unexplored by, and unincorporated into, mainstream economics because of its methodological constraints (Gilpin 2001).

The neoclassical perspective is, however, still useful in explaining essentially market-coordinated transactions such as arm's-length trade and international portfolio investments, for which the sellers and buyers of real and financial assets remain pricetakers. In fact, the international financial markets have been driven largely by market forces and highly integrated to form the global market economy. But this perspective alone is insufficient to understand the reality and dynamics of the world economy.

\section{***SEE FIGURE $1 * * *$}

In contrast, business economists (especially in the discipline of international business) have been developing a different but complementary perspective. For them, the world economy is more often than not hierarchically (or organizationally) coordinated by multinational corporations--that is, guided by the "visible hand". This transnational corporate economy is fundamentally an imperfect market, a global constellation of 
"islands of conscious power in this ocean of unconscious co-operation" (Robertson 1960). While emphasizing hierarchical coordination, business economists nevertheless accept both markets and organizations as institutional arrangements to coordinate economic activities in the world market, since multinational corporations do not always internalize their activities (i.e., they also resort to the market, depending on the nature of transactions).

Multinational corporations, the major architect of this hierarchically coordinated world economy, emerged before World War I, but the rise of the transnational corporate economy is largely a post-World-War-II phenomenon. In the 1950s and 60s, multinationals were synonymous with American corporations because of the dominance of the US economy at that time. In the subsequent decades, however, Europe and Japan soon spawned their own multinationals, challenging the US dominance. More recently, those rapidly catching-up developing countries too have become homes for multinationals. Hence, the transnational corporate economy, initially dominated by US corporations in a pyramidal shape, has been somewhat "flattened", though the multinationals from the advanced world are still dominant throughout the world.

Moreover, there have emerged other key non-corporate players. Multilateral international institutions (such as GATT-turned WTO, IMF, the World Bank, OECD, ITO, UN agencies, and regional development banks), most of which were established before the rise of the transnational corporate economy, are now actively engaged in interacting with, and assisting, the national sovereign economies which are increasingly involved with multinationals as their homes and hosts and which therefore are often in need of regulating or reining in these footloose corporations. Non-governmental 
organizations (NGOs) are similarly making their presence known and taken seriously as countervailing power in the transnational corporate economy; they themselves are "multinational" in organization and operations. In other words, the transnational corporate economy has become a multi-stakeholder entity.

In short, a bifurcated perspective - that is, the national sovereign economy (controlled by nation-states) vs. the global market economy (driven by the market)--has so far prevailed. But the world economy needs to be conceived as a triumvirate interactive system composed of the national sovereign economy (polity-governed), the global market economy (market-dictated), and the transnational corporate economy (organization-coordinated).

\section{Growth of the Transnational Corporate Economy}

Stephen Hymer (1960/1976), the father of the theory of the multinational firm, explained why some national firms were compelled to go overseas to produce locally and under what conditions such firms would be able to compete and succeed in foreign markets despite "the stigma of being foreign." In his "product-life-cycle" theory, Raymond Vernon (1966) explored how R\&D-based exports, initially from the United States, were destined to be replaced by overseas production as new technologies are standardized. The firms were thus led to leave the confines of their sovereign economies and eventually operate globally in a cross-border economic zone. These scholars were among the first to conceptualize the origination of the transnational corporate economy.

Yet these early theories did not explain why the firms, which go overseas, would operate in the transnational corporate economy (that is, to "internalize" transactions) instead of the global market economy (that is, to "externalize" transactions). The 
necessary explanations were later provided in terms of transaction cost economics (Williamson 1975; Caves 1982). Intangible assets, especially knowledge and skills, are not susceptible to market-coordination because of opportunism, information compactedness and asymmetry, and asset specificity. Hence, their cross-border transfers and exchanges have to be "internalized" within a firm.

John Dunning's "eclectic paradigm of international production" (1988) goes beyond the role of firm-specific intangible assets as a determinant of international production. It is based on the triple conditions that a firm must meet if it is to invest and produce abroad: (1) the possession of ownership (or O) advantages vis-à-vis the firms of other nationalities in serving a particular overseas market; (2) it should be more profitable to use such $\mathrm{O}$ advantages within its hierarchy (i.e., to internalize); and (3) it must be in the interests of the firm to utilize $\mathrm{O}$ advantages in conjunction with at least some factor inputs outside its home country. In other words, Dunning explains how and under what conditions a national firm transforms itself into a successful multinational firm operating in the transnational corporate economy.

More recently, other scholars have introduced a number of global manufacturing models. For example, the models that describe the new spatial arrangements of crossborder production are represented by a cross-border model of "commodity chains" (Gereffi and Korzeniewicz 1994) and the "global production network" theory (Ernst 2002a and $\mathrm{b}$ ). While the former is concerned primarily with the distribution of economic rents, the later explores how changes in corporate networking practices enhance the mobility of knowledge. All these conceptual constructs provide further elaborations of the makeup of the transnational corporate economy. 
In addition to the real-sector (manufacturing) theories of international production, however, the models of "financial chains" and "global financial networks" seem equally called for to give specific frames of reference for financial transactions. Yet cross-border financial transactions are on the whole market-coordinated in the highly competitive market environments despite the fact that large financial institutions (such as big banks and securities firms) exist. Hence, the conventional perspective of the global market economy may suffice.

It should be noted that underlying all these theoretical developments are (i) technological progress in transportation and communications and (ii) deregulation and liberalization. In sum, the growth of the transnational corporate economy is a product of the evolutionary extension of business activity across borders, technological advance, and institutional and political change.

\section{Waves of globalization, Now and Before}

The post-World-War-II rise of the transnational corporate economy differs fundamentally from the pre-World-War-I wave of globalization. Some argue that the current trend of globalization is merely an extension of the pre-World-War-I occurrence of globalization and that "the world economy was actually more integrated at the end of the nineteenth century" (Streeten 2001). Trade statistics - exports or imports --are usually employed by neoclassical economists to measure the extent and magnitude of globalization. But such an indicator, though informative, misses the structural characteristics and dynamics of present-day globalization in which hierarchical coordination at the hands of multinationals plays a dominant role in economic integration. 
In this connection, Kevin O'Rourke and Jeffrey Williamson's Globalization and History: The Evolution of a Nineteenth Century Atlantic Economy (1999) is relevant in shedding light on the critical difference between the two waves of globalization. Their study presents a comprehensive analysis of the first round of globalization (1985-1914) in terms of a received neoclassical framework, the Heckscher-Ohlin-Samuelson factorendowment theory. They argue that the driving mechanisms of globalization are (i) cross-border factor movements (labor migration and capital flows) and (ii) international trade, both of which were substantially liberated due to reductions in transportation and communications costs (railroads, steam ships, and the telegraph) and Britain's unilateral free trade stance. Although not mentioned by O'Rourke and Williamson, the 1885-1914 world was fundamentally the global market economy, a world economy whose structural barriers luckily declined, enhancing the market mechanism. In those days trade was therefore carried out mostly at arm's-length (not intra-company trade as it is now often the case), massive labor migration from the Old World to the New World was driven largely by the market (that is, by wage differentials), and capital flows were dominated by portfolio investments. Thus, all these international transactions were basically conducted via the relatively well-functioning global market economy which happened to be created by the liberalization of trade, labor migration, and investment under the Pax Britannica.

In contrast, the current round of globalization cannot be sufficiently explained in terms of such an analytical framework alone. The rise of the transnational corporate economy has altered the world economy fundamentally. The current globalization is strongly organizationally coordinated, as well as market driven, entailing the intricate 
relationships among all the stakeholders--the sovereign economies, multinationals, multilateral organizations, and NGOs.

\section{Relationships between National Sovereign Economy and Transnational Corporate Economy}

The national sovereign economy and the transnational corporate economy have had a delicate and alternating "love and hate" relationship. This vicissitude is well reflected in a trilogy of study on relations between multinationals and governments made by Raymond Vernon. Sovereignty at Bay (1971) captured the suddenly dominating power of multinational corporations over the sovereign economies in the 1950s and the 1960s. Subsequently, the balance of power quickly shifted in favor of the nation states in the wake of expropriations by the developing host governments of foreign-owned corporations, notably in the resource-extractive industries and utilities, especially from the mid-1960s to the mid-1970s. This turn of events was analyzed in Storm over Multinationals (1977). Most recently, In the Hurricane's Eye (1998) examined an ambivalent state of calmness in which the sovereign economies and the transnational corporate economy came to coexist in utilitarian, though precarious, harmony.

The mercurial relationship between the two systems has continued to be reflected in many scholars' works. Kenichi Ohmae declared The Borderless World (1990) and The End of the Nation State (1995) and stressing the obsolescence of the national sovereign economy. On the other hand, Dani Rodrik posed a question: Has Globalization Gone Too Far? (1998) and answered: "Not if policymakers act wisely and imaginatively," leaving room - and obligations--for national policymakers in coping with the social costs of globalization. 
Some nation-centric views have likewise surfaced: "Reports of the Death of the National Economy is Greatly Exaggerated" (the title of Robert Wade's book chapter, 1996); The Myth of the Global Corporation (Doremus, et. al. 1998) and The End of Globalization (Rugman 2000) have been the representative recent reposts. Robert Gilpin $(2001,102)$ rejects "the popular idea that universal laws and powerful economic forces now rule the global economy." Yet Gilpin acknowledges that the nation-state is in retreat toward its more modest late-nineteenth-century status, so far as the advanced world, especially in the United States, is concerned, but that "the forces of nationalism, industrialization, and state-creation" are again on the rise throughout the developing world. In other words, so far as the developing world is concerned, the national sovereign economy has begun to pragmatically capitalize on the outreach of the transnational corporate economy for industrialization purposes.

Indeed, the forces of nationalism, industrialization, and state-creation on the part of the developing host nations are leading to the new regime of "MNC-cum-host collaborative growth" (Ozawa 2000) or to the new mode of cooperation between "multinationals and governments as co-endogenizers of growth" (Ozawa and Castello 2001). This new regime flourished in pre-crisis Asia, notably the Asian NIEs (Singapore, Hong Kong, Taiwan, and Korea) and ASEAN-4 (Thailand, Malaysia, the Philippines, and Indonesia). Although it was momentarily disrupted and weakened by the financial crisis, it still continues to persist. Particularly in China, the regime of collaborative growth successfully operates as the engine of structural upgrading and growth. It should also be noted that many developing countries either refuse to insert themselves fully into or have begun to fend themselves off the global market economy through which short-term 
speculative money flows occur. China, for example, still effectively controls both capital inflows and outflows to avoid any detrimental effects on its domestic economic stability. In the wake of their currency crises Malaysia—and mostly recently Argentina—imposed restrictions on capital outflows.

\section{Welfare Implications of the Triumvirate World}

In neoclassical economics the emergence of an international economy as an extension of sovereign economies in the form of the global market economy is considered welfare-improving. Within the static framework of the Heckscher-Ohlin theory, it is accepted that both free trade and factor movement enhance economic welfare for the world as a whole but that free factor movement is superior to free trade when endowments differ substantially among nations, substantially enough to defy the forces of factor price equalization.

As explained earlier, the transnational corporate economy has come into existence because intangible assets are not amenable to market coordination because of transaction costs. In this respect, then, the transnational corporate economy supplements the global market economy in facilitating the cross-border transfer of intangible assets, thereby further enhancing economic welfare.

Yet neither the global market economy nor the transnational corporate economy is free from operational deficiencies. When it comes to financial flows, the former has turned out to be quite volatile and unstable for the very reason that transactions are coordinated by market forces; speculative investments and investors' herd-like mentality have led to the cycles of financial boom and bust in Asia, Russia, Latin America, and other places. Unfortunately the market has no sense of social obligations. It is often said 
that "Like fire, the market is a good servant, but a bad master" (Eatwell 1982). The market is neither goal-setting nor goal-pursuing; it is goal-neutral at best and sometimes even goal-hindering (not a good servant!); it is merely a resource-allocating institution (Ozawa 1997).

In contrast, the transnational corporate economy can be pressured to deal with the social consequences and other backwash effects of globalization, especially in the context of its increasingly multi-stakeholder nature. After all, the transnational corporate economy is coordinated "consciously" (that is, administratively by specific organizations) - hence, can be held accountable, whereas the market can never be held responsible for its consequences (say, the disastrous consequences of a currency crisis or a bubble). In this respect, the sovereign economies, especially in the developing world, may feel more comfortable with the rise of the transnational corporate economy than with that of the global market economy. 
Figure 1. The Triumvirate World Economic System

A. National Sovereign Economy (NSE) and Global Market Economy (GME) (Neoclassical perspective)

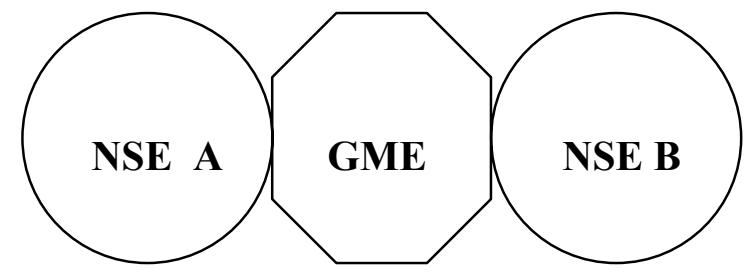

B. National Sovereign Economy (NSE) and Transnational Corporate Economy (TCE)

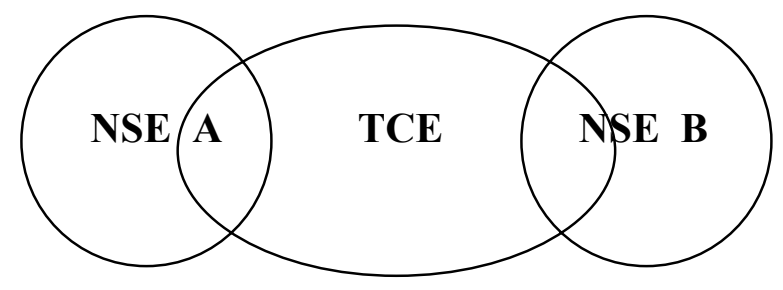

C. National Sovereign Economy, Global Market Economy, and Transnational Corporate Economy (Triumvirate World Economy)

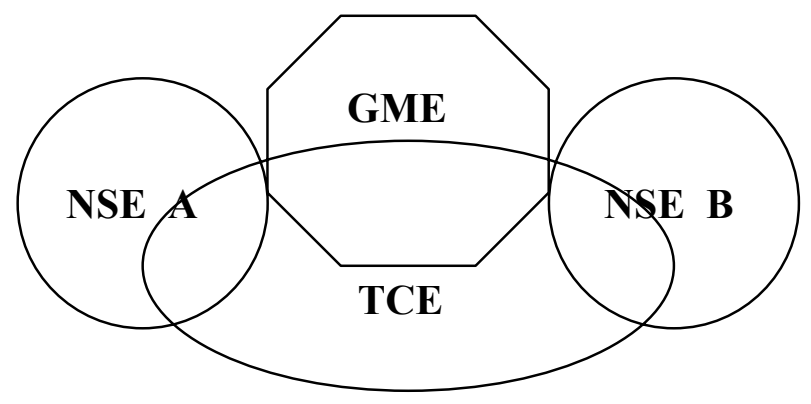




\section{References}

Doremus, Paul N., William W. Keller, Louis W. Pauly, and Simon Reich (1998). The Myth of the Global Corporations, Princeton: Princeton University Press.

Dunning, John H. (1988). Explaining International Production, London: Unwin Hyman.

Eatwell, John (1982). Whatever Happened to Britain? The Economics of Decline, London: British Broadcasting Corporation.

Ernst, Dieter (2002a). "Global Production Networks and the Changing Geography of Innovation Systems: Implications for Developing Countries," Working Paper, Economics Series No. 9, East-West Center, Honolulu, Hawaii.

---------(2002b). “The New Mobility of Knowledge: Digital Information Systems and Global Flagship Networks, " in Cooperation and Conflict in a Connected World, edited by R. Latham and S. Sassen, New York: Social Science Research Council.

Gereffi, Gary and Miguel Korzeniewicz (1990). "Commodity Chains and Footwear Exports in the Semiperiphery," in Semiperipheral States in the World Economy, edited by William Martin, Westport, Conn.: Greenwood Press.

Gilpin, Robert (2001). Global Political Economy: Understanding the International Economic Order, Princeton: Princeton University Press.

Hymer, Stephen (1960). The International Operations of National Firms: a Study of Foreign Direct Investment, Ph.D. dissertation, Massachusetts Institute of Technology; later published by MIT Press, 1976.

Ohmae, Kenichi (1990). The Borderless World: Power and Strategy in the Interlinked Economy, New York: Harper Business.

(1995). The End of the Nation State: The Rise of Regional Economies, New York: Free Press.

O'Rourke, Kevin and Jeffrey Williamson (1999). Globalization and History: The Evolution of a Nineteenth Century Atlantic Economy, Cambridge, Mass.: MIT Press.

Ozawa, Terutomo (1997). "Japan," in Governments, Globalization, and International Business, edited by John Dunning, Oxford: Oxford University Press.

(2000). "The 'Flying-Geese' Paradigm: Toward a Co-Evolutionary Theory of MNC-Assisted Growth," in The New World Order: Internationalism, Regionalism and the Multinational Corporations, edited by K. Fatemi, Amsterdam \& New York:

Pergamon. 
--------- and Sergio Castello (2001). “Toward an 'International Business’ Paradigm of Endogenous Growth: Multinationals and Governments as Co-Endogenisers," International Journal of the Economics of Business 8, No. 2; 211-228.

Pasinetti, Luigi L. (1993). Structural Economic Dynamics: A Theory of the Economic Consequences of Human Learning, Cambridge, UK: Cambridge University Press.

Paul Streeten (2001). "Integration, Interdependence, and Globalization," Finance \& Development 38, No. 2, June: 34-37.

Robertson, D. H. (1960). The Control of Industry, Cambridge, UK: Cambridge University Press.

Rodrik, Dani (1998). Has Globalization Gone Too Far? Washington D.C.: Institute for International Economics.

Rugman, Alan (2000). The End of Globalization, London: Random House.

Vernon, Raymond (1966). "International Investment and International Trade in the Product Cycle," Quarterly Journal of Economics 80, No. 2, May: 190-207.

--------(1971). Sovereignty at Bay: The Multinational Spread of U.S. Enterprises, New York: Basic Books.

---------(1977). Storm over Multinationals: The Real Issues, Cambridge, Mass.: Harvard University Press.

(1998). In the Hurricane's Eye: The Troubled Prospects of Multinational Enterprises, Cambridge, Mass.: Harvard University Press.

Wade, Robert (1996). "Globalization and Its Limits: Reports of the Death of the National Economy are Greatly Exaggerated," in National Diversity and Global Capitalism, edited by Suzanne Berger and Ronald Dore, Ithaca, N.Y.: Cornell University Press.

Williamson, Oliver (1975). Market and Hierarchies: Analysis and Antitrust Implications, New York: Free Press. 